\title{
The Implementation of Akhlaq Education Values in Academic Services at STIT Al Hikmah Tebing Tebinggi
}

\author{
Saiful Akhyar Lubis ${ }^{1}$ Neliwati1 ${ }^{1}$ \& Ficki Padli Pardede ${ }^{2 *}$ \\ 1 Postgraduate of Universitas Islam Negeri Sumatera Utara, Medan, Indonesia \\ 2 Doctoral Student of Universitas Islam Negeri Sumatera Utara, Medan, Indonesia \\ *Corresponding Author: fickipardede@gmail.com
}

\begin{abstract}
This study article analyzes fonomena in implementing the values of moral education in academic services at STIT Al Hikmah Tebing Tinggi. The research method used in this research is qualitative with a phonomenology approach, which is to analyze the fonomenes in the implementation of the values of moral education at STIT Al Hikmah Tebing Tinggi. Based on the review of the explanation of the research results of the article above, it can be concluded that the following findings are that planning the implementation of moral education values in academic services by stipulating a standard rule of academic ethics involving lecturers, educational staff, and students. Implementing the implementation of moral education values in academic services by 1) providing an academic guidebook for the entire academic community that has been compiled by integrating the values of moral education. 2) Conducting public lectures to socialize about the academic ethics of STIT Al Hikmah Tebing Tinggi. 3) Oversee the development of the planning implementation by holding weekly meetings for the academic managers of STIT Al Hikmah Tebing Tinggi. 4) Provide sanctions and rewards for lecturers, students and exemplary education staff at STIT Al Hikmah Tebing Tinggi. Strategies in implementing the values of moral education in the learning process and academic services of STIT Al-Hikmah Tebing Tinggi by 1) Establishing academic ethics guidelines by integrating the values of moral education. 2) Building a sense of kinship through academic counseling, 3) modeling and habituation.
\end{abstract}

Keywords: moral education values; academic services; akhlaq

\section{Introduction}

Islam teaches to always make morals a part of life in life, while the essence of faith and good deeds is morals (Syukur, 2010: 67). This explains that Islam cannot be separated from morals and the reflection of faith is morals. Morals are important for the children of the nation's generation, morals have an important influence in the life of the nation and state. So whether or not it is resilient, its sustainability, misery or welfare of a nation depends on the morals of its inhabitants. To achieve these noble morals, education is needed here. So, if moral education continues to be planted from birth to adulthood, it is possible that a generation that has morals will grow. Cultivation of morals is given gradually and runs continuously until good deeds are embedded in the child's soul. This means that educational institutions are a strategic place in moral education. More than that, Islamic tertiary institutions in particular are institutions for creating generations that provide change in society with moral values.

The difficulty in implementing moral education in educational institutions today is of course influenced by various factors. One of the most felt causes is the lack of good role models in our educators as examples that can be imitated and digested by students, besides that the rapid development of information flows also affects children's personalities. The freedom of information, which is marked by the increasingly sophisticated technology and access to use it, which is available everywhere, shapes the child's mindset according to what he sees. Based on this, the role of parents and educational institutions is needed to serve as a filter. Meanwhile, students who have been equipped with moral awareness/feelings of morality since being born into the world are fitrah. It is understood that the tendency to have good character is inherent in every human being from birth, so all actions that deviate from good character are deviations and against their nature. So in this case, educational institutions must create a conducive environment for learning and adequate facilities. Education needs to understand the morals of each student so that the curriculum is applied appropriately and accordingly and the teacher must provide guidance to students both in class and 
outside the classroom. The moral education that is implemented is truly achieved so that a good culture is created in the school environment. Based on this, students are presented with moral education with the right method, educators, both teachers and lecturers, always provide advice to students about morals and provide good role models. Not only that, as educators always establish good communication not only to students but also to parents as a form of good cooperation.

At the higher education level, moral education is a stage of moral formation that is no less important than moral formation at the school level. Research on moral or character education in schools has been preceded by research by Wahyudin (2012), Ismaraidha (2016), Abdul Hamid (2016), this research emphasizes more on school education only. The importance of moral education in educational institutions in schools, so in carrying out moral education it focuses on development by emphasizing the religious atmosphere at school. Basically, moral education in Higher Education is a must because basically in Higher Education applies the concept of transfer of knowledge. So in this case higher education is important to carry out moral education but in a different context. The point is that moral education which is applied focuses more on implementation in the campus environment both in the learning process and in academic services. Based on the observations made at STIT Al Hikmah Tebing Tinggi, students seem to have behaved which indicates that they practice morals. The habit of students at STIT Alhikmah Tebing Tinggi is to say greetings to the lecturers when they meet, students are still reluctant to ride along with those who are not mahram when entering the campus area. On the other hand, when entering the prayer time, the learning activities stop and all students and the academic community pray at the mosque. When class hours enter students who are only one or two late, this is because the campus is far from their home. This is what motivates the conduct of research at STIT Alhikmah Tebing Tinggi, with the aim of seeing how the strategy and implementation of moral education at STIT Al-Hikmah Tebing Tinggi which is the goal of the campus community is to turn STIT Alhikmah Tebing Tinggi students into intellectual and moral campuses. .

The purpose of moral education is basically to encourage the birth of good humans, who have attractive, ethical, modest, honest, intelligent, caring, and tough personalities. This is also the main goal for STIT Al Hikmah Tebing Tinggi in producing alumni who devote themselves to society well and become role models. In line with this, Zulfahri explained that every student doing KPM in various villages always received a good reception from the community. There are even some villages that ask the campus to send KPM students to their area. He explained again that students always do careful planning for community service so that in community activities they are always active and provide role models and the latest breakthroughs to the community. Such as the establishment of several TPQs, PAUDs in collaboration with the village, which are accommodated by the campus. Based on the explanation of the background above, the results of the study describe the factors regarding the implementation of the values of moral education at the Al Hikmah Tebing Tinggi Institute of Sciences (STIT) and academic services.

\section{Research Method}

This study uses qualitative research or a qualitative interactive mode of inquiry, which is an in-depth study that uses techniques directly dealing with people in their natural setting in collecting data (Millan, 2001: 35). Researchers try to describe the context of the research interactively, explain various informants' perspectives on phenomena, and continuously explore, search for, and analyze data about the phenomenon being studied from experiences while in the field. The approach used in this research is a phenomenological approach. The phenomenological approach is an approach that focuses on obtaining descriptive data about how the subject or informant understands or gives meaning to the phenomenon under study. This research was conducted at STIT AL Hikmah Tebing Tinggi which has the address jl. Gatot Subroto Km. 3, Lubuk Raya, Padang Hulu District, Tebing Tinggi City, North Sumatara.

One of the main requirements in qualitative research is the existence of researchers in the field, in qualitative research the researcher is the primary instrument for data collection and analysis, where the researcher is the main instrument in data collection and analysis (Merriam, 1988). Thus the presence of research is calling it a key instrument or key instrument in research. So, because it is the main instrument or key instrument, researchers will be actively involved in directly observing all phenomena or events that occur during research activities, from the beginning to the end of data collection. As a consequence of the main or key instruments, the researcher is required to extend the time in collecting data in the field or prolonged data collection.

The collection and analysis of qualitative data takes place in an interactive and overlapping manner, therefore it is not called a procedure but a data collection and analysis strategy. Furthermore, in all qualitative data collection, the research phases are relatively the same, starting from: (1) the planning phase, (2) the initial phase of collecting data, (3) the basic or basic data collection phase, (4) the ending phase data 
collection, and (5) data completion phase. The technique of collecting data in this research is in the form of observation (observation), interviews, documents and field notes. After the necessary data and information have been collected, they are analyzed in order to find the meaning of the findings. Data analysis took place and was carried out throughout the study. Therefore, since the beginning of the study, the researcher has started searching for the meaning of the informants' behavior patterns, explanations, possible confirmations, causal pathways and noting regularities. The data analysis steps are data reduction, data presentation and conclusions. In the context of this research, the strategy the researcher uses to ensure the validity of the research data, namely:

1. Extend the time to collect data in the field.

2. Perform triangulation in data collection and analysis.

3. Make basic conclusions.

4. Member checks.

5. Discuss with peers.

6. Complete all field notes and neatly organize any data that has been collected.

7. Do self critique.

\section{Results and Discussion}

3.1 Planning in implementing the values of moral education in academic services at STIT Al-Hikmah Tebing Tinggi

Tarbiyah College of Science (STIT) Al-Hikmah Tebing Tinggi as one of 42 PTKIS in North Sumatra under the supervision of Kopertais Region IX North Sumatra. STIT Al-Hikmah Tebing Tinggi is the development of the Al-Hikmah Medan Islamic College (STAI) which was officially changed in 2004. As written on the notary certificate, STIT Al-Hikmah is under the Al Hikmah Islamic College Foundation (YASPETIA ) which currently manages 4 (four) study programs, namely the Islamic Religious Education Study Program (PAI), the Madrasah Ibtidaiyah Teacher Education Study Program (PGMI) and Early Childhood Islamic Education (PIAUD) and Mathematics Education/Tadris (TMM). Tarbiyah Al Hikmah Tebing Tinggi School of Science has a vision to become a superior and competitive Islamic university at the regional and national levels in developing Islamic disciplines and akhlakul karimah-based education by 2030.

Higher education is a forum for educating adult humans, therefore to implement the values of moral education at STIT Al Hikmah Tebing Tinggi, both in the learning process and in academic services, have a mutually supportive relationship which in essence is to produce moral alumni. To give birth to this generation, of course it cannot be separated from the learning process and academic services to students. In the learning process, the implementation of moral education values covers learning activities that are dominated by lecturers. Whereas in academic services, here the role of the manager of STIT Al Hikmah Tebing Tinggi is in serving students for the ongoing lecture activities until the end which cannot be separated from the values of moral education in the implementation of these services. The values of moral education that are integrated in the syllabus material of the courses taught are stated in the vision and mission of STIT Al Hikmah Tebing Tinggi, namely spiritual values, honesty and tolerance. These three values are the concepts that are implemented in the learning process and academic services at STIT Al Hikmah Tebing Tinggi.

To provide services to students, in this case involving the entire academic community in providing services to students so that educational activities are carried out for students properly. As one of the manifestations of institutional efforts in the field of the birth of agent of change graduates who have good character, various policies have been established in academic ethics and rules of behavior on campus that must be obeyed and bind the entire academic community. This predetermined device is a very appropriate means of changing student attitudes, which is one indicator of the success of the educational process. The main goal in which is success is a change in behavior for the better. This is where the main point of the educational goal is the change in behavior based on Islamic values. Thus, the targets and targets of education are basically not only in the quantity of graduates with tantalizing academic achievements, but more importantly the ethics and behaviors that underlie the development of knowledge and science that give birth to education which is a more important target.

The values of moral education in the academic service process in the life of STIT Al Hikmah Tebing Tinggi are implemented to oversee the procession of student development during the teaching and learning process. So, in academic services in building moral education values is to create a good learning process. The values of moral education in academic services are set as standard rules involving lecturers, education staff, and students. These three things are the main components in the academic community. Academic ethics involves the entire academic community, not only students. Because if the lecturers and education staff have good friends, the students will also follow and imitate them. 
The academic process that runs at STIT Al Hikmah collaborates cooperatively with other related work units in order to achieve the goals of STIT Al-Hikmah Tebing Tinggi. Without good cooperation, the vision and mission of the campus will be constrained, this is because the lecturers play their own role. So, in this case, lecturers must have competence in carrying out their duties and adhere to operational standards, work procedures and be oriented towards efforts to improve work quality. Lecturers must make themselves an important part of STIT Al Hikmah Tebing Tinggi. So in this case, the role of lecturers in providing academic services cannot be separated from the tridarma of higher education. So in this case STIT Al Hikmah Tebing Tinggi integrates the values of moral education to the academic ethics.

As part of the academic community, educational staff instill in them to always work diligently, disciplined, loyal, sincere and obey the rules/policies of the Foundation, STIT Al-Hikmah Tebing Tinggi. To support this, in this case the educational staff must always try to improve the knowledge and skills that must be possessed to support their duties as educational staff. This knowledge and skills are in accordance with Islamic values.

3.2 Implementation in implementing the values of moral education in academic services at STIT AlHikmah Tebing Tinggi

Basically as a student, it is a major milestone in changing the face of education. This is the most important thing in making that knowledge a different face with the same face. Students must uphold the name and noble values of STIT Al-Hikmah Tebing Tinggi wherever they are. Students are also expected to do their best to be able to finish studies quickly with the best possible results. So in this case, the STIT Al Hikmah Tebing Tinggi makes a policy that is contained in student ethics.

By nature of creation, humans with their various potentials in the form of organs, senses and body tissues always aim to find the truth. Humans were created by Allah SWT complete with their potential and even equipped with religious teachings to regulate their life not only in this world, but also in the hereafter when they have to face the Creator. Academic ethics and rules of behavior on campus, especially at STIT Al Hikmah Tebing Tinggi are a concept of morality that must be carried, instilled and implemented by all academicians. Academic ethics are determined based on Islamic values by integrating the values of moral education. The moral education values referred to here are morals that rely on Islamic spiritual religious values that have been rooted in the body of the Indonesian nation and are in accordance with the culture of the majority of religious Indonesians. Thus, in order to produce quality graduates with morals, one of the factors that cannot be avoided is the provision of moral education values in the learning process and quality and influential mental spiritual development for students and other academicians.

STIT Al Hikmah as a campus of civilization, in this case to cadre STIT Al Hikmah graduates who are smart, innovative, sensitive to the conditions around them, creatively looking for solutions to every nation's problems, independently based on moral education values. The point is students who are knowledgeable based on Islam with broad horizons and based on the values of moral education. So STIT Al Hikmah graduates must always strive to optimize the ability and potential of this nation for the advancement of the Indonesian nation which will ultimately affect the progress of world civilization. Especially for this pluralistic Indonesian nation, STIT Al Hikmah graduates must have a strong and correct moral foundation based on the spiritual religion adopted by this nation. So based on this, to build the upholding of academic ethics and rules of behavior by integrating the values of moral education is identical to the struggle to create a superior generation not only in terms of scientific abilities, but also from spiritual and moral maturity that is always balanced following their development. The ability and willingness of all academicians who have a high commitment in upholding ethics and rules of conduct on campus are expected to create an academic atmosphere that is conducive to the sustainability of the teaching and learning process.

Based on the description of the explanation, academic services at STIT Al Hikmah Tebing Tinggi involve the entire academic community, namely lecturers, education staff, and students. The values of moral education that are integrated into academic ethics are inseparable from the three basic concepts of moral education values which serve as guidelines in forming a moral campus. The three values are spiritual values, honesty values in academic ethics, and tolerance values in pluralism. Planning for the implementation of moral education values in academic services involves the academic manager, namely the chairman, vice chairman, head of study program, and other educational staff. Planning carried out in the first lecture for new students and old students by providing guidelines for academic ethics. To monitor the development of the planning, it is discussed at the weekly academic manager meeting. In detail, it can be described as follows:

1. Providing an academic guidebook for the entire academic community that has been compiled by integrating the values of moral education.

2. Conducting public lectures to socialize about the academic ethics of STIT Al Hikmah Tebing Tinggi

3. Oversee the development of the planning implementation by holding weekly meetings for the academic 
managers of STIT Al Hikmah Tebing Tinggi.

4. Provide sanctions and rewards for lecturers, students and exemplary education staff at STIT Al Hikmah Tebing Tinggi.

Service is essentially intangible in nature, to meet needs in achieving academic goals. So in this case, the academic services carried out at STIT Al Hikmah are to improve the quality of the campus with a different color, namely giving birth to students who are knowledgeable and have good character. By achieving these goals, it will provide satisfaction for alumni in particular and society in general. If the service received exceeds the expectations of the community, it is perceived as an ideal service quality. Likewise, if the quality of service received is lower than expected, the quality of service is perceived as bad or unsatisfactory. Whether or not the quality of service in satisfying students depends on the ability of service providers to consistently meet the expectations or desires of students and education users.

The main objective of implementing the values of moral education at STIT Al Hikmah is to form a complete personality towards all student activities to demonstrate devotion to Allah and submission to Him. The understanding of the Muslim person differs in the view of society, some even understand it narrowly so that it is as if the Muslim person is reflected in people who are only diligent in practicing Islam from the ubudiyah aspect, even though that is only one aspect that must be attached to the person of a Muslim. This is the main measure in attaching the values of moral education to students so that this personality has an impact on rahmatallil alamin. So in this case, students play a role in society to strengthen relationships between communities. With this role, students become a place to solve community problems, this is where the role of students as agents of change. This is the fundamental goal of STIT Al Hikmah to build a civilization campus with good morals. To achieve this goal, it involves a learning process and academic services that focus on making students comfortable in learning and accustomed to good morals.

\subsection{Strategies in implementing moral education values in the academic services of STIT Al-Hikmah} Tebing Tinggi

Efforts to realize the planning of the implementation of moral education values both in the learning process and in academic ethics must have the right strategy. This is because, the target that becomes the application is students who have cognitive maturity and experience a period of identity. If the strategy used is not correct, there will be rejection by students, on the other hand, students will spend more time outside the campus than at the campus itself. The strategy used in implementing this includes the learning process and academic services. This is because the main objective in implementing the values of moral education at STIT $\mathrm{Al} \mathrm{Hikmah}$ is to form students who have morals. Both in the learning process and in academic services are a place to make these changes. So, the expected quality of higher education requires universal and professional management of the resources that exist in STIT Al Hikmah Tebing Tinggi.

Efforts made by STIT Al Hikmah Tebing Tinggi to develop campuses in order to obtain information applied on campus to support campus programs. Based on this, it can be understood that the strategies carried out by lecturers and education staff in implementing the values of moral education in detail can be explained as follows:

\section{Establish Academic Ethics Guidelines by Integrating Moral Education Values}

Higher education institutions are part of other social institutions that can act as a critical culture and foster a spirit of tolerance to strengthen a multicultural society. The problem of higher education at this time is the conflict of interests between ideologies based on academic values and those based on corporate values. Academic values are ethical-utopian values, while corporate values are pragmatic practical values. The tug of war between ideological interests in education is actually a tug of war between idealism and pragmatism. On the one hand, education has a role in shaping public life, and even a more precise statement does not just affirm the role of education in public life, but precisely what kind of public life is being shaped by the world of education.

This is where the role of higher education is to form the uniqueness of higher education itself, as is the case at STIT Al Hikmah Tebing Tinggi that the uniqueness formed is based on morals with a moderate touch. Thus the alumni are not narrow in society, with the concept of pluralism, the Islamic mission of rahmatalil'alamin can be achieved. Education is believed to be able to play a significant role in shaping the dynamic and cultural life of society. Thus students who are formed at STIT Al Hikmah must be able to provide legitimacy for certain forms of social life. The goal is that universities can become the basis for educational institutions with academic values. So the task of higher education here is to provide enlightenment for the academic community and the wider community. When higher education is far from society, higher education becomes anti-reality, uprooted from the social roots of students. Anti-reality education is a systematic impact of the dominance of the ideology of pragmatism in education. In the vortex 
of pragmatism, academicians are led to think practically, instantaneously, and pragmatically. They are increasingly far removed from philosophical thinking which sharpens their minds and makes them critical of the text and context. This is where it is necessary to return the campus academic ethical culture based on technocratic rationality to critical rationality.

The achievements made by STIT Al Hikmah are part of the community, because the campus consists of various ethnicities and other religions who are prepared to be present in the community. So in this case, academic ethics guidelines are standard rules that must be followed by the entire academic community. With these guidelines, the goal is that the entire academic community can become an ethical culture. If this is achieved, it will become a habit in the community. The main emphasis is on lecturers covering the tridarma of higher education and campus development. If lecturers become accustomed to this, it will have an impact on students.

STIT Al Hikmah prepares students to have academic and professional abilities as well as develop, disseminate and practice knowledge, to reach the pleasure of Allah SWT. Science and technology are gifts from God Almighty that should be grateful as blessings and mercy and are used for the welfare of society and humanity. Lecturers as academic persons at STIT Al Hikmah as a mission in carrying out their duties, are given the authority as educators, researchers, and service providers to the community. To carry out this mandate, lecturers can involve students in exercising this authority which is given academic freedom and academic preaching freedom. This authority and freedom demands standardized responsibility through various regulations, also based on the appreciation and practice of high moral values in accordance with the moral values that develop in the general public and the academic community. So, if lecturers are rooted in academic ethics, they will be accustomed to implementing the tridarma of higher education.

The values of moral education that are integrated into academic ethics that must be lived up to by the lecturers and students have been standardized. These values are always developing so that not all relevant academic ethical values can always be standardized in the form of a code of ethics. For this reason, lecturers, education staff and students must always hone their conscience to act and behave honestly, fairly, humbly, and sincerely and upholds the dignity of mankind based on Islamic values. Lecturers and students are required to always increase their potential, achieve and maintain their own image, this is because lecturers are role models in academic activities and role models in social activities. Climate which is part of what has become character. This is the most important thing to standardize academic ethics by integrating the values of moral education.

It should be understood here that high schools, when viewed from the perspective of service use, are industries that interact directly between service providers and service users, so in this case there are several things that are important to note, namely reliability, responsiveness, assurance, empathy and physical evidence. all of which cannot be separated from the values of moral education. So, a standard rule will initially force it to follow, then it will become habituation and gradually become a culture. This is where the essence of this strategy is, written rules are rules that must be followed and cannot be separated from sanctions and rewards.

Based on the description of the explanation above, it can be concluded that the strategy of standardizing academic ethics by integrating the values of moral education can improve the quality of academic services and the learning process. To achieve this quality, there must be a match between service quality and the learning process based on the values of moral education with student academic satisfaction. The development of STIT Al Hikmah from its inception was inseparable from the development of an ethical academic culture. So to develop the quality of education, it is necessary to develop an academic culture by building values and norms that display an academic atmosphere with the values of moral education. The culture is an atmosphere that is in accordance with scientific values and principles in an effort to acquire and develop knowledge by controlling the values of moral education. This atmosphere is needed, maintained, fostered and developed in accordance with the conditions faced by the campus. The values of moral education are the basis for developing education and becoming a culture in daily implementation in the academic sphere, so that the goals of STIT Al Hikmah can be achieved.

Although basically higher education aims at a process of transfer of culture or transfer of knowledge (transfer of knowledge) but STIT Al Hikmah strives for more of the process of transfer of value (transfer of value). Islamic higher education in particular makes a godly human being who can achieve success in life in this world and the hereafter. The success of the afterlife cannot be separated from the improvement of morals, because intelligence that is not controlled by morals will destroy others. So in this case, education is something that everyone needs, because with education it will lead someone to a better direction. Through academic ethics, the managers of STIT Al Hikmah must be able to build an academic atmosphere and create a comfortable and orderly educational climate to achieve comprehensive educational goals. The implementation of academic ethics requires a systematic implementation, this is because academic ethics in its concept and implementation will bind one aspect of education to another. When all these aspects of ethics 
will build an atmosphere of learning and service processes in a diverse, pluralistic, multicultural scientific community in an institution. The involvement of moral education values in academic ethics in the implementation of the teaching and learning process and academic services is an important factor in improving the quality of college graduates. The vision of STIT Al Hikmah which has been integrated into the values of moral education and the academic climate can encourage the entire academic community to take advantage of more learning activities and guide students.

This development is carried out either by integrating spiritual values, honesty and tolerance values, these values which build a sense of harmony in educational institutions. Thus there will be no among students and the campus to suspect and disrespect each other, because it will weaken and will make educational institutions will not last long. The values of moral education that are built into academic ethics to be implemented at STIT Al Hikmah Tebing Tinggi are the result of the learning and training process, this is because STIT Al Hikmah stands alone with a young age. It can be said that to implement the values of moral education in academic ethics at STIT Al Hikmah is done through engineering environmental factors. So through academic ethics guidelines give birth to further strategies in implementing the values of moral education in the learning process and academic services. Among other things, can be done through a strategy that includes modeling and habituation that is done consistently, and reinforcement.

\section{Building a sense of kinship through academic counseling}

Academic counseling is meant here is to take a personal approach to build a sense of kinship. Basically, the human problem is a central theme and a starting point in providing meaning in Islamic higher education, this is because education basically wants to lead humans to true humanity in accordance with the nature of their creation. In line with this, the position of humans in the educational process, the function of education is primarily concerned with directing humans to certain goals and finding their life goals. So in the end education will return to the essence of human presence on this earth, namely as the caliph and servant of Allah. This is where the role of higher education is, so that students are able to give a deep enough meaning to their lives that deliver fitrah towards ideal ideals (mardhatillah). Here, the role of moral education values in the higher education institution is to give birth to a generation of agents of change who are moral and aware of who they are so that they can carry out the mission of Islam which is rahmatallil 'alamin. In principle, thoughts like this have resulted in many emergence of contemporary educational concepts.

Basically, students and the academic community in living their lives certainly require solutions to the problems at hand. So by fostering a sense of kinship it will make it easier to implement the values of moral education, this is because every problem faced by the entire academic community will hinder, hinder, and narrow the possibility of achieving something. Thus the solution is very complex, so that the alternative conceptual and operational technological offer must be oriented towards the complexity of students as academic persons. Therefore, psychological approaches in the form of psychotherapy, counseling, and so on are alternative approaches to build a sense of kinship. One form of operational problem solving is the counseling concept using face to face relationship and personal contact techniques. In the end, counseling and ethics are components that can unite in a life system in the environment of STIT Al Hikmah Tebing Tinggi.

So in this case, academic counseling helps students to be able to solve their problems in order to achieve peace of mind in a life that is safe and blessed by Allah, has istiqamah to be able to do self-counseling for themselves. To guide students and the academic community, a correct and solid reference is needed. So in this case, STIT Al Hikmah forms a rule regarding counseling for students and lecturers and educational staff. The role of counseling in higher education is not only the process of providing assistance to solve student or lecturer problems, but to build a sense of kinship in order to re-realize its existence as a creature of God which should in religious life always be in accordance with the provisions and instructions of Allah, so as to achieve happiness. Live in this world and the hereafter. If a sense of kinship is built, they will be able to understand and solve their problems in order to adjust themselves and be able to live in harmony with God's provisions and instructions so that they can achieve the happiness of life in the world and in the hereafter. With the implementation of academic guidance and counseling that focuses on the religious aspects of the academic community, it will be able to elevate human life even higher, not only from the worldly side but in the end.

\section{Exemplary and Habit}

Exemplary and habituation strategies are strategies that require self-awareness and an emphasis on lecturers and education staff. Whereas for students the emphasis is more on habituation which is encouragement and motivation. Basically, the learning process in higher education, especially STIT Al Hikmah Tebing Tinggi, if you look at the curriculum, there are very few subjects that lead to moral education. So one of the efforts 
made by STIT Al Hikmah is to integrate the values of moral education in the curriculum and student extracurricular activities. On the other hand, the strategy carried out in implementing the values of moral education is by modeling and habituation strategies. Exemplary and habituation for the academic community will provide an implicit basic framework in implementing the values of moral education. Students are one component of the higher education system which occupies a central position in the learning process which is always a problem and as a focus of attention. This is where the role of lecturers in directing student behavior to achieve their learning goals through action is not just a concept. Therefore, students need to be equipped with a model of habituation and meaningful experiences, especially those related to daily life, because each lecturer also has a responsibility to bring students to a certain level of maturity.

It can be concluded that the strategy of refraction and modeling can build a construct of moral education through the implementation of moral education values. The achievement of this mission through exemplary and habituation strategies because these strategies can:

1. Instilling moral values for students

2. Cultivate, strengthen faith and devotion for students and lecturers

3. Forming the whole personality

4. Improve student skills, creativity and responsibility

5. Expanding the morals of the students' friendships and strengthening independence.

One of the things done by STIT Al Hikmah Tebing Tinggi in supporting the success of activities in implementing the values of moral education through the strategy of habituation is trying to provide facilities or funding through campus operational funds in collaboration with student parents, other agencies in raising funds for activities -activities that support the mission. In this case, STIT Al Hikmah Tebing Tinggi does not limit communication with students so that student activities are not constrained. So that students get used to doing activities that build interaction with students and the campus. Operationally, the efforts made by STIT Al Hikmah in implementing the values of moral education through the habituation strategy are as follows:

1. Accustom students to uphold discipline.

2. Getting students used to maintaining cleanliness.

3. Familiarize students with maintaining order.

4. Accustom students to maintain honesty.

5. Accustom students to have an attitude of mutual help.

6. Provide assignment or supervision

In the learning process, modeling and habituation strategies are very appropriate conditions to be implemented. To realize these expectations, lecturers have a very important role, especially in implementing the values of moral education through habituation and exemplary strategies in the learning process. The rules of conduct at STIT Al Hikmah Tebing Tinggi which have been standardized as guidelines and centers for the teaching and learning process, cultural transformation, civilization development and the implementation of other higher education functions, need to be maintained so that they are always conducive to improving quality and implementing optimal functions. On the other hand, STIT Al Hikmah in general, the rules of behavior on campus contain rights and obligations, activities and permits, behavior and clothing, gambling, possession of weapons and explosives, various prohibitions related to drugs, liquor, psychotropic and cigarettes to harassment and sexual offenses. In detail, the scope of the rules of conduct on campus is a guideline for the entire academic community while living and interacting with the campus community. So in this case, through exemplary and habituation strategies it will build a situation for the entire academic community to implement the values of moral education at STIT Al Hikmah Tebing Tinggi.

Based on the phenomena described above, it is very appropriate if STIT Al Hikmah echoes the campus icon of civilization, civilization cannot be built if intellectual, spiritual and moral are not united. Strengthening the faith of academicians both through the learning process and academic services. This is an urgent matter for the managers of STIT Al Hikmah to establish a campus curriculum and academics that are truly integrated with spiritual values, honesty and tolerance values in order to build the power of understanding the correct faith as a foundation in religious life, so that academicians will be avoided of despicable acts. Thus, building a strong and true religious spirit must go hand in hand with building a society that is moral and civilized as well as intelligent in faith. Islamic teachings teach peace, and if all of this is followed and used as a foundation in implementing ethics and rules of behavior on campus, it will lead people to live a life of peace, happiness and prosperity. With the above activities, it is hoped that they will be able to implement the moral values of students. Because of good morals, its formation and development can not only be through lessons, but also supported by religious activities. With these activities, he can realize them with good and real examples so that they can help implement the moral values 
of the students. Apart from the above activities, implementation can be done anywhere, when in class, outside of class, when sharing together. These activities are balanced with the existence of rules to regulate the morals or behavior that are expected to occur in students, so that students have a good personality. Without an automatic discipline, the implementation of the moral values of the students will not be able to be tangible, on the contrary, by carrying out the existing order, it will automatically form students who have good character.

The formation of morals in students will form good behavior towards themselves and others. High school in accordance with its vision and mission is an institution that produces superior human resources as a vehicle for producing quality products to be able to compete in the global market. So in this case, students are a vital and central element in a high school, and it seems very important to understand the factors that determine student satisfaction with high school considering that students are more idealistic. STIT Al Hikmah has an interest in fulfilling various dimensions of satisfaction, especially students, for the realization of quality student output so that they can make the best contribution in their service for the benefit of society. High school managers, including the need to have an obsession to build a high commitment to quality improvement so that the costs incurred by students are not in vain. So, STIT Al Hikmah also provides evidence that maintaining trust in the desires of student parents to become qualified and moral people.

\section{Conclusion}

Based on the review of the explanation of the research results of the article above, the following findings were concluded that planning the implementation of moral education values in academic services by stipulating a standard rule on academic ethics involving lecturers, education staff, and students Implementing the implementation of moral education values in academic services by 1) Providing an academic guidebook for the entire academic community that has been compiled by integrating the values of moral education. 2) Conducting public lectures to socialize about the academic ethics of STIT Al Hikmah Tebing Tinggi. 3) Oversee the development of the planning implementation by holding weekly meetings for the academic managers of STIT Al Hikmah Tebing Tinggi. 4) Provide sanctions and rewards for lecturers, students and exemplary education staff at STIT Al Hikmah Tebing Tinggi. Strategies in implementing the values of moral education in the learning process and academic services of STIT Al-Hikmah Tebing Tinggi by 1) Establishing academic ethics guidelines by integrating the values of moral education. 2) Building a sense of kinship through academic counseling, 3) modeling and habituation.

\section{References}

B, Merriam Sharan. (1988). Case Study Research in Education: A Qualitative Approach, San Francisco: Jossy-Bass Publishers.

Hamid, Abdul. (2016). Metode Internalisasi Nilai-Nilai Akhlak Dalam Pendidikan Agama Islam Di SMP N 17 Palu (Method of Internalizing Moral Values in Islamic Religious Education at SMP N 17 Palu), in Ta'lim, Jurnal Pendidikan Agama Islam, Vol.14, No. 2.

Ismaraidha. (2016). Implementasi Pendidikan Akhlak Pada Mata Pelajaran PAI di SD IT Ulul IlmiIslamic School Medan Denai" ("Implementation of Moral Education in Islamic Education Subjects at SD IT Ulul Ilmi Islamic School Medan Denai"), Thesis: UIN SU.

Millan, James H. Mc. dan Sally Schummer. (2001). Research in Education: A Conceptual Introduction, New York: Longman.

Syukur, Amin. (2010). Pengantar Studi Islam (Introduction to Islamic Studies), Semarang: Pustaka Nuun.

Tim Penyusunan (Compilation Team) STIT Al Hikmah Tebing Tinggi, Buku Panduan Akademik STIT Al Hikmah Tebing Tinggi (Academic Handbook of STIT Al Hikmah Tebing Tinggi), Tebing Tinggi: Unit Percetakan STIT Al Hikmah Tebing Tinggi, 2019.

Wahyudin. (2012). Model Pendidikan Akhlak Di Sekolah: Sebuah Model Pengembangan Suasana Religius di Sekolah (Model of Moral Education in Schools: A Model for Developing a Religious Atmosphere in Schools "), in Jurnal Madania, 2(1). 